\title{
Cladoceran (Crustacea: Branchiopoda) biodiversity of protected areas in a Brazilian hotspot
}

\author{
F.D.R. Sousa',2, L.M.A. Elmoor-Loureiro², L. Mendonça-Galvão, ${ }^{2,3}$, \\ E.A. Panarelli ${ }^{4}$, T.F. Arruda ${ }^{2,5}$, B.G. Fagundes ${ }^{2}$ \\ ${ }^{1}$ Unidade Acadêmica Especial de Ciências Biológicas, Universidade Federal de Jataí - UFJ, BR \\ 364 km 195 n³800, CEP 75801615, Jatai,,GO,Brazil.E-mail:fdiogo.rs@gmail.com \\ ${ }^{2}$ Grupo de Estudos de Ecossistemas Aquáticos - GEEA, Universidade Católica de Brasília, Brazil. \\ ${ }^{3}$ Laboratório de Biodiversidade Aquática, Universidade Católica de Brasília, Sala M-204, QS 07, \\ Lote 01, EPCT, Taguatinga, DF 71966-700, Brazil. \\ ${ }^{4}$ Universidade do Estado de Minas Gerais, "Campus" de Frutal, Rua Mário Palmério, 1001, \\ 38200-000, Frutal, Minas Gerais, Brazil. \\ ${ }^{5}$ Fakultät für Forstwissenschaften und Waldökologie, George-August Universität Göttingen, \\ Büsgenweg 5, 37077 Göttingen, Germany.
}

\begin{abstract}
As less than 50\% of the Cerrado Biome area in Brazil maintains its natural characteristics, its indigenous fauna and flora have been confined to the few areas designated for protection. However, a significant part of the protected areas in the Cerrado still need to be studied, and little attention is given to the aquatic biota. In this study, we present a study of the Cladocera fauna in 11 preserved areas of this Biome. Altogether, the protected areas harbor 59 species. Representatives of the Chydoridae family were found in all areas. The number of species observed in some areas represented a substantial pool of the total regional richness (sometimes more than $1 / 3$ of all known species). Besides that, low similarities between protected areas were observed $(<50 \%)$. We can speculate that these areas are able to maintain different biological components in the case of the Cladocera. Despite the high number of protected areas in the Cerrado Biome, our results can still be taken as underestimates of richness and endemism.

How to cite this article: Sousa F.D.R., Elmoor-Loureiro L.M.A., Mendonça-Galvão L., Panarelli E.A., Arruda T.F., Fagundes B.G. 2018. Cladoceran (Crustacea: Branchiopoda) biodiversity of protected areas in a Brazilian hotspot // Invert. Zool. Vol.15. No.3. P.309322. doi: 10.15298/invertzool.15.3.09
\end{abstract}

KEY WORDS: Cerrado, endemism, conservation units, species richness, savanna.

\section{Биоразнообразие Cladocera (Crustacea: Branchiopoda) в его «горячей точке» на охраняемых территориях Бразилии}

\author{
Ф.Д.Р. Соуза ${ }^{1,2}$, Л.М.А. Элмур-Лоурейро², Л. Мендоса-Гальвайо²,3, \\ Э.А. Панарелли ${ }^{4}$ Т.Ф. Арруда ${ }^{2,5}$, Б.Г. Фагундес ${ }^{2}$

\footnotetext{
${ }^{1}$ Unidade Acadêmica Especial de Ciências Biológicas, Universidade Federal de Jataí - UFJ, BR 364 km 195 n³800, CEP 75801615, Jatai,,GO,Brazil.E-mail: fdiogo.rs@gmail.com

${ }^{2}$ Grupo de Estudos de Ecossistemas Aquáticos - GEEA, Universidade Católica de Brasília, Brazil.

${ }^{3}$ Laboratório de Biodiversidade Aquática, Universidade Católica de Brasília, Sala M-204, QS 07, Lote 01, EPCT, Taguatinga, DF 71966-700, Brazil.
} 
${ }^{4}$ Universidade do Estado de Minas Gerais, "Campus" de Frutal, Rua Mário Palmério, 1001,
$38200-000$, Frutal, Minas Gerais, Brazil.
5 Fakultät für Forstwissenschaften und Waldökologie, George-August Universität Göttingen,
Büsgenweg 5, 37077 Göttingen, Germany.

РЕЗЮМЕ: Поскольку лишь менее половины территории Бразилии, занимаемой «серрадо» как особым биомом, находится в ее естественном состоянии, фауна и флора данной территории наиболее богата в нескольких областях, предназначенных для сохранения этого биома. Однако, значительная часть охраняемых территорий серрадо нуждается в изучении, в частности, мало внимания уделяется изучению водной биоты. В данной работе мы исследовали фауну Cladocera в 11 охраняемых областях, занимаемых данным биомом. Всего найдено 59 видов кладоцер. Представители семейства Chydoridae были найдены во всех областях. Пул видов отдельных областей представляет собой существенный вклад в общий пул регионального биоразнообразия (более трети известных видов). Кроме того, фауна отдельных охраняемых регионов имеет низкие значения сходства $(<50 \%)$. Мы можем предположить, что в разных областях в случае Cladocera поддерживается специфическое разнообразие. Принимая во внимание большое число охраняемых областей серрадо, полученные данные могут быть неполными как в оценке биоразнообразия, так и степени эндемичности фауны кладоцер.

Как цитировать эту статью: Sousa F.D.R., Elmoor-Loureiro L.M.A., Mendonça-Galvão L., Panarelli E.A., Arruda T.F., Fagundes B.G. 2018. Cladoceran(Crustacea: Branchiopoda) biodiversity of protected areas in a Brazilian hotspot // Invert. Zool. Vol.15. No.3. P.309322. doi: 10.15298/invertzool.15.3.09

КЛЮЧЕВЫЕ СЛОВА: серрадо, энднмизм, единица сохранения биоразнообразия, видовое богатство, саванна

\section{Introduction}

Due to its high biological diversity and endemism the Brazilian Cerrado is considered one of the 25 most endangered areas in the world (Myers et al., 2000; Myers, 2003), despite apparent human influences. Currently less than $50 \%$ of the Cerrado Biome area maintains its natural characteristics (Ganem et al., 2013), and inevitably, its indigenous fauna and flora have been confined to the few areas that are designated for conservation (Maury, 2002).

Unfortunately, the areas that protect the Cerrado fragments still lack surveys that can define their real biodiversity, which could help us in the improvement of a conservation regime (Klink, Machado, 2005; Oliveira et al., 2017). One of these deficiencies, pointed out by Agostinho et al. (2005), is the lack of attention given to the aquatic biota in the definition of strategies for selection of the conservation units in Brazil, leading to underestimates of the total biodiversity. In other words, even the already established conservation units still need to be studied. Assessing species diversity (richness and composition) in aquatic systems within protected areas and identifying patterns and processes is very important for understanding the ecological dynamics of such units and setting targets to define more conservation areas (Lawrence et al., 2011; Hermoso et al., 2016). This should be taken as a priority for the conservation of Cerrado, as well as other Biomes found in Brazilian territory.

The Brazilian Cerrado is considered a biodiversity hotspot, and its high endemism level has been recognized (Klink, Machado, 2005). It is supposed that a large number of the aquatic ecosystems present in this Biome may harbor a high species diversity, as demonstrated by Reid 
(1984, 1987, 1993a, b) when studying the Copepoda from diverse environments. In the case of the Cladocera, the knowledge on the diversity of species found in aquatic ecosystems of the Cerrado has increased in recent years (see the project https://cladocera.wordpress.com), including the ones located in protected areas (Sousa, ElmoorLoureiro, 2012, 2013; Sousa et al., 2013). Despite all the efforts made, the Cerrado Biome has a vast territorial extent and shelters about 382 protected areas of differentmodalities, showing that many gaps still need to be filled. The objective of this study was to evaluate the richness and composition of the Cladocera fauna observed in some preserved areas of this Biome.

\section{Material and Methods}

The Cerrado is the second-largest South American Biome, which comprises 2 million square kilometers of the national territory, occupying the Brazilian Central Plateau (Bustamante et al., 2012). The region presents a wide variety of aquatic ecosystems, as numerous springs, shallow lakes, wet grasslands and loworder lotic systems, which flow along eight of the 12 Brazilian great river basins (PadovesiFonseca, 2006; Lima, Silva, 2006). It comprises a vegetation type associated to special ecological conditions where "savanna vegetation dominates, but it is not exclusive", being interspersed with riparian or gallery forests, patches of semideciduous forest, swamp and/or marshes (Bourlière, Hadley, 1983).

Cerrado climate is Aw (rainy tropical, according to Köppen classification) marked by strong seasonality, with a rainy season from October to April concentrating up to $80 \%$ of annual precipitation (mean temperature around $29^{\circ} \mathrm{C}$ ), and a dry season from May to September when precipitation ranges from zero to below $50 \mathrm{~mm}$ (mean temperature around $18^{\circ} \mathrm{C}$ ). Annual mean precipitation is around $1500 \mathrm{~mm}$, ranging from 750 to $2000 \mathrm{~mm}$ (Silva et al., 2008). Soils in the Cerrado Biome are mostly Latossolos (46\%), according to the Brazilian Soil Classification, which corresponds to Oxisols in the US soil classification. These typical- ly tropical soils are weathered and highly acidic, poor, with a low cation-exchange capacity (CEC), deep and well drained and show a high levels of exchangeable aluminum; their high permeability can be compared to sandy soils (Reatto, Martins, 2005). Near streams, Gleissolos (there is no analogous type in US Soil Taxonomy, although the Aquox suborder would be similar) are also common (Silva et al., 2011). These are reduced hydromorphic soils generally occupying landscape depressions frequently flooded (Reatto, Martins, 2005).

The present study was based on two data sources: literature data and the analysis of samples collected in Sempre Vivas National Park, Serra da Canastra National Park, Chapada dos Guimarães National Park, Chapada dos Veadeiros National Park, IBGE Reserve, and Terra Ronca State Park (Fig. 1). The samples evaluated in this study were taken using a plankton net (mesh size of $50,68,80$ or $100 \mu \mathrm{m}$ ) and preserved in ethanol or $4 \%$ formaldehyde. Different kinds of water bodies (wetlands, streams, rivers, and ponds), habitats (plankton, bottom sediment, aquatic macrophytes, leaves, and litter from riparian zone) located in different altitudes were sampled (Table 1). The samples were screened under a stereomicroscope, and all the cladoceran individuals were identified based on a specialized literature (e.g., Smirnov, 1992, 1996; Elmoor-Loureiro, 1997; Kotov et al., 2004; Kotov, Stifter, 2006; Sinev, ElmoorLoureiro, 2010; Van Damme et al., 2010, 2011). Jaccard similarity index and cluster analysis were used to evaluate species composition among protected areas. A rarefaction analyses was used to evaluate the sampling effort. Also, the nonparametric estimator Jackknife 1 (based on incidence data) was used to evaluate the estimated species richness. These analyses were carried out using the program PAST (Hammer et al., 2001).

\section{Results and Discussion}

In total, were observed in the protected areas evaluated 59 species belonging to the families Sididae, Daphniidae, Ilyocryptidae, Macrothri- 


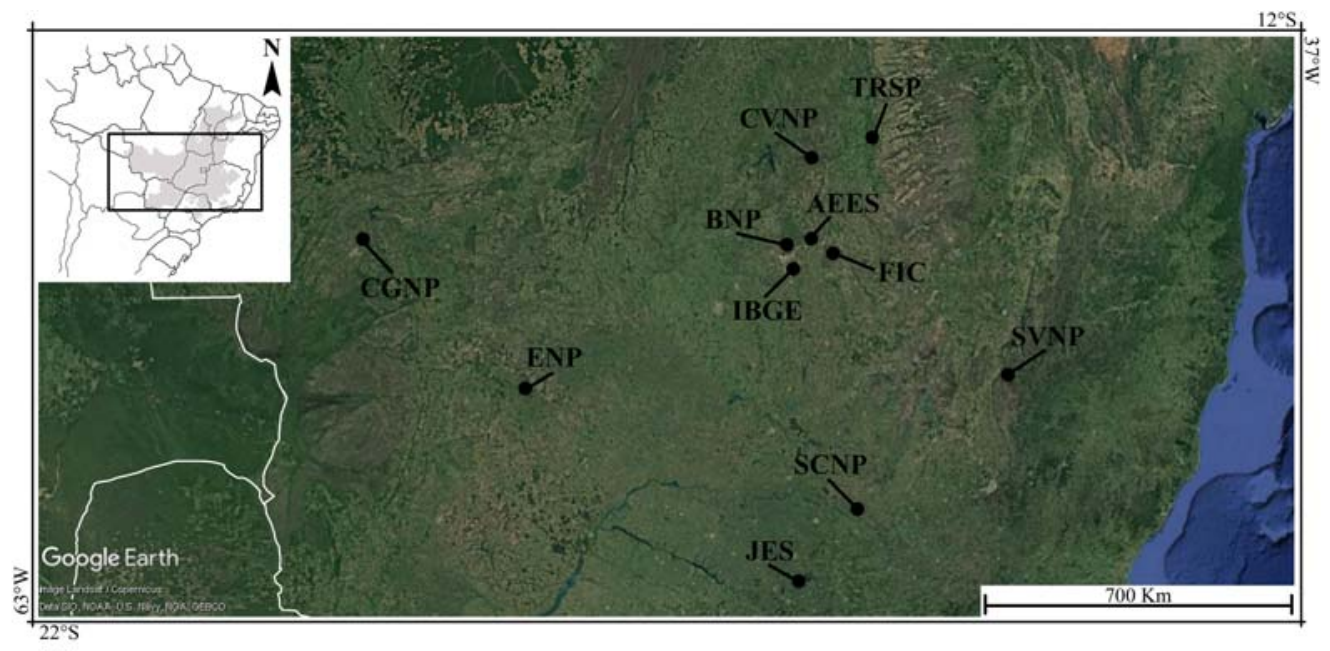

Fig. 1. Map of localization of the Cerrado Biome (grey) and studied protected areas. FIC - Formosa's Instructional Camp; AEES - Águas Emendadas Ecological Station; JES - Jataí Ecological Station; IBGE — IBGE Ecological Reserve; TRSP — Terra Ronca State Park; BNP — Brasília National Park; CVNP — Chapada dos Veadeiros National Park; CGNP — Chapada dos Guimarães National Park; ENP — Emas National Park; SVNP — Sempre Vivas National Park; SCNP — Serra da Canastra National Park.

Рис. 1. Карта расположения биома серрадо (закрашен серым цветом) и локализации исследованных охраняемых территорий. FIC — Formosa's Instructional Camp; AEES — Águas Emendadas Ecological Station; JES — Jataí Ecological Station; IBGE — IBGE Ecological Reserve; TRSP — Terra Ronca State Park; BNP — Brasília National Park; CVNP — Chapada dos Veadeiros National Park; CGNP — Chapada dos Guimarres National Park; ENP — Emas National Park; SVNP — Sempre Vivas National Park; SCNP — Serra da Canastra National Park.

cidae, Bosminidae and Chydoridae (Table 2). The estimated species richness of the protected areas was $74.4( \pm 4.9)$ species, which corresponds to the absence of an asymptote on the rarefaction curve (Fig. 2A). In other words, more sampling effort is necessary to improve our knowledge about cladoceran biodiversity in protected areas. The highest richness values were observed in SVNP and AEES, and the lowest in CGNP, JES, and TRSP (Fig. 2B). In some protected areas, the number of species represent a substantial contribution to the regional richness. For example, in the Federal District 56 cladoceran species (Sousa, ElmoorLoureiro, 2012; Sousa et al., 2013) were reported, and the number of species observed for AEES and BNP, two principal protected areas in this region, was about $50 \%$ of the total richness (Fig. 2). Likewise, the representativeness of the Cladocera taxa reported from conservation units in the state of Minas Gerais was also very high, being almost a third of the total richness (Santos-Wisniewski et al., 2011).

In addition to being the primary conservation strategy practiced in Brazil (Mattar et al., 2018), the creation of protected areas was based on the idea that such areas need to have the capacity to harbor different ecosystems and different biological components (Heny-Silva, 2005). From this point of view and based only on our results, protected areas such as FIC, AEES, BNP, ENP, CVNP, and SVNP can harbor almost all the cladoceran lineages, represented by different families (Fig. 3). The family Chydoridae was present in all studied areas, and it was the single cladoceran lineage observed in JES and CGNP (Table 2).

As expected, the Chydoridae comprised the highest number of species in all protected areas, which is the usual pattern observed in different ecosystems of Brazil and everywhere. The Chydoridae is the most diverse cladoceran lineage, 


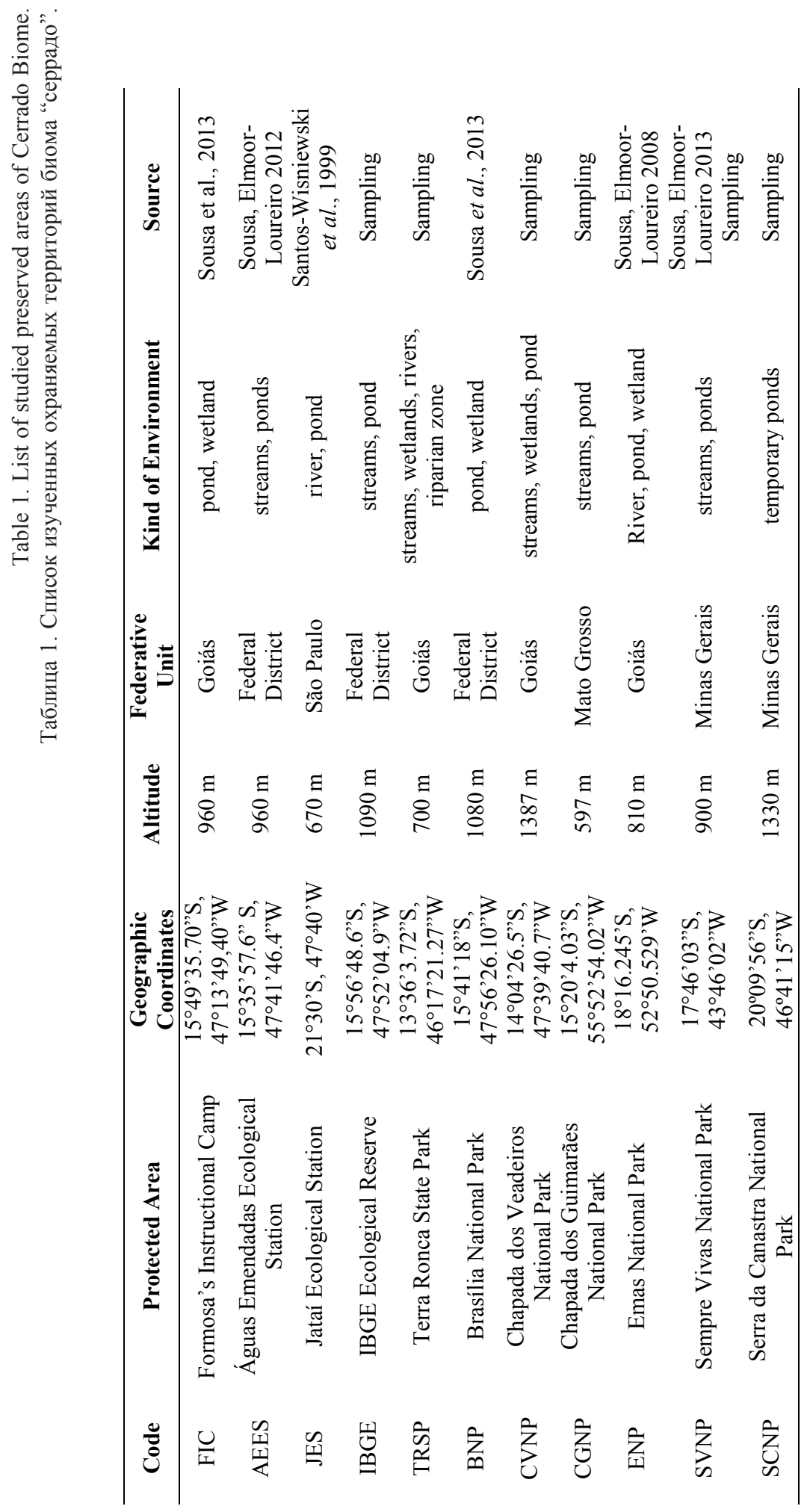




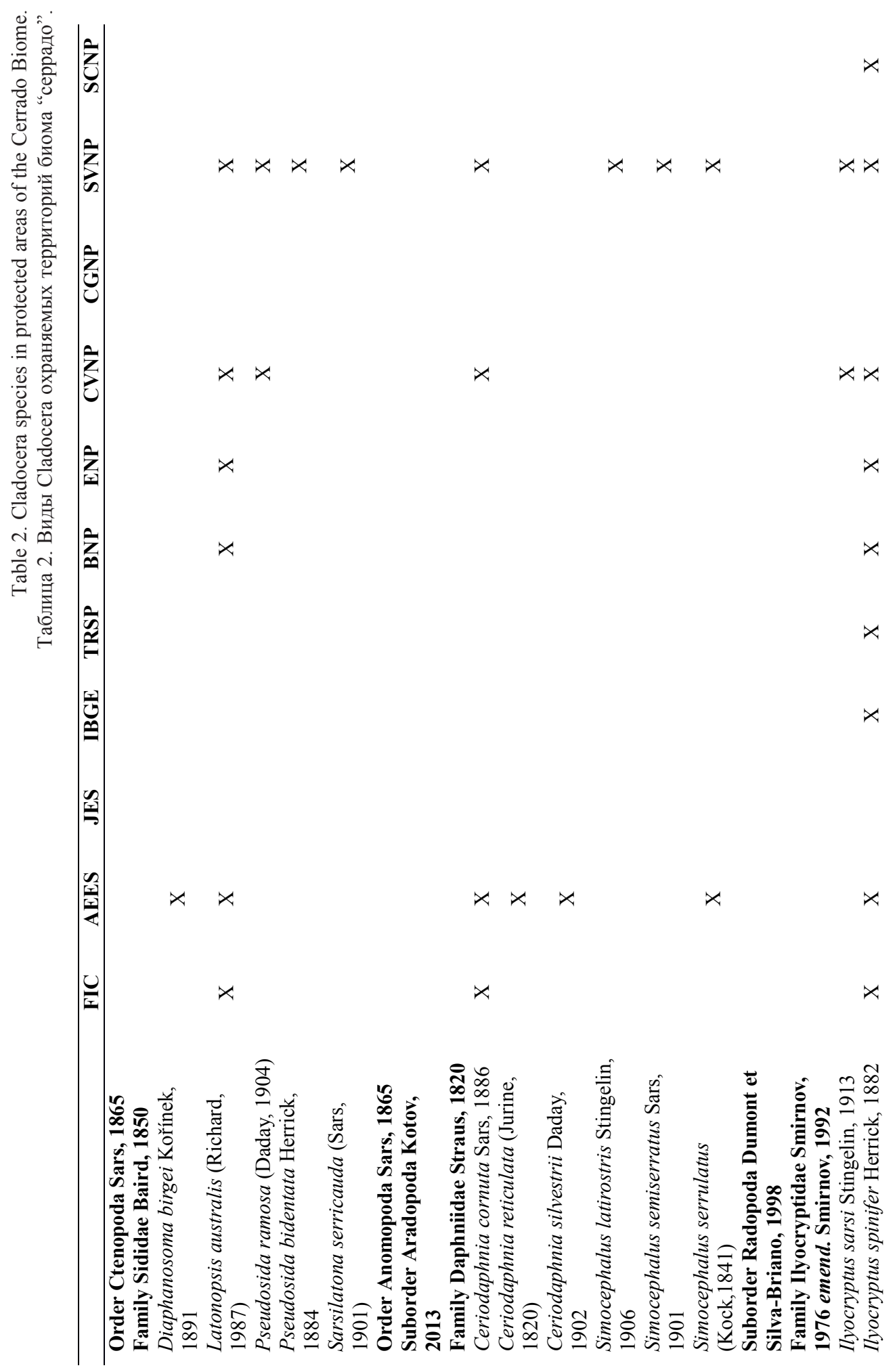



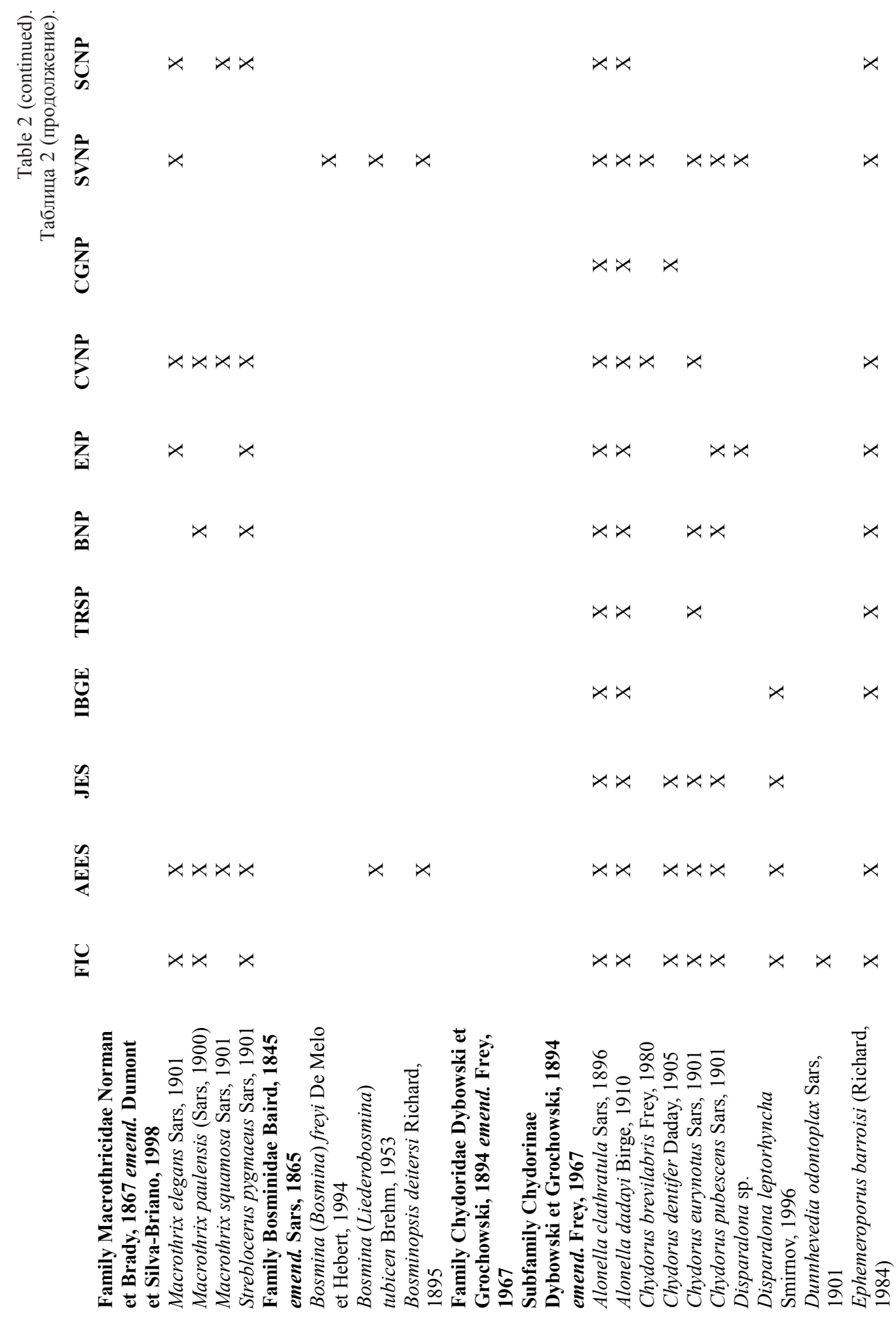

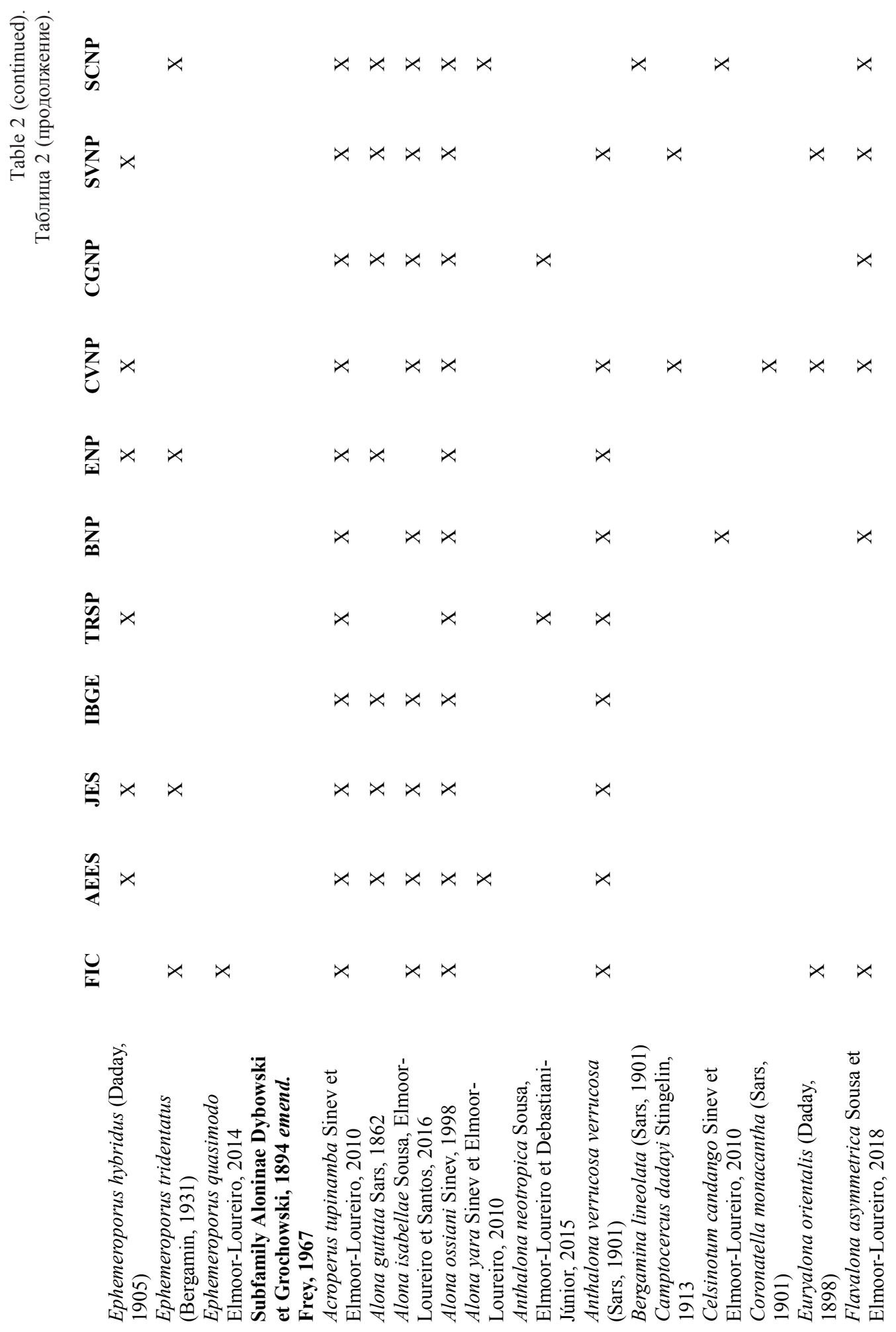

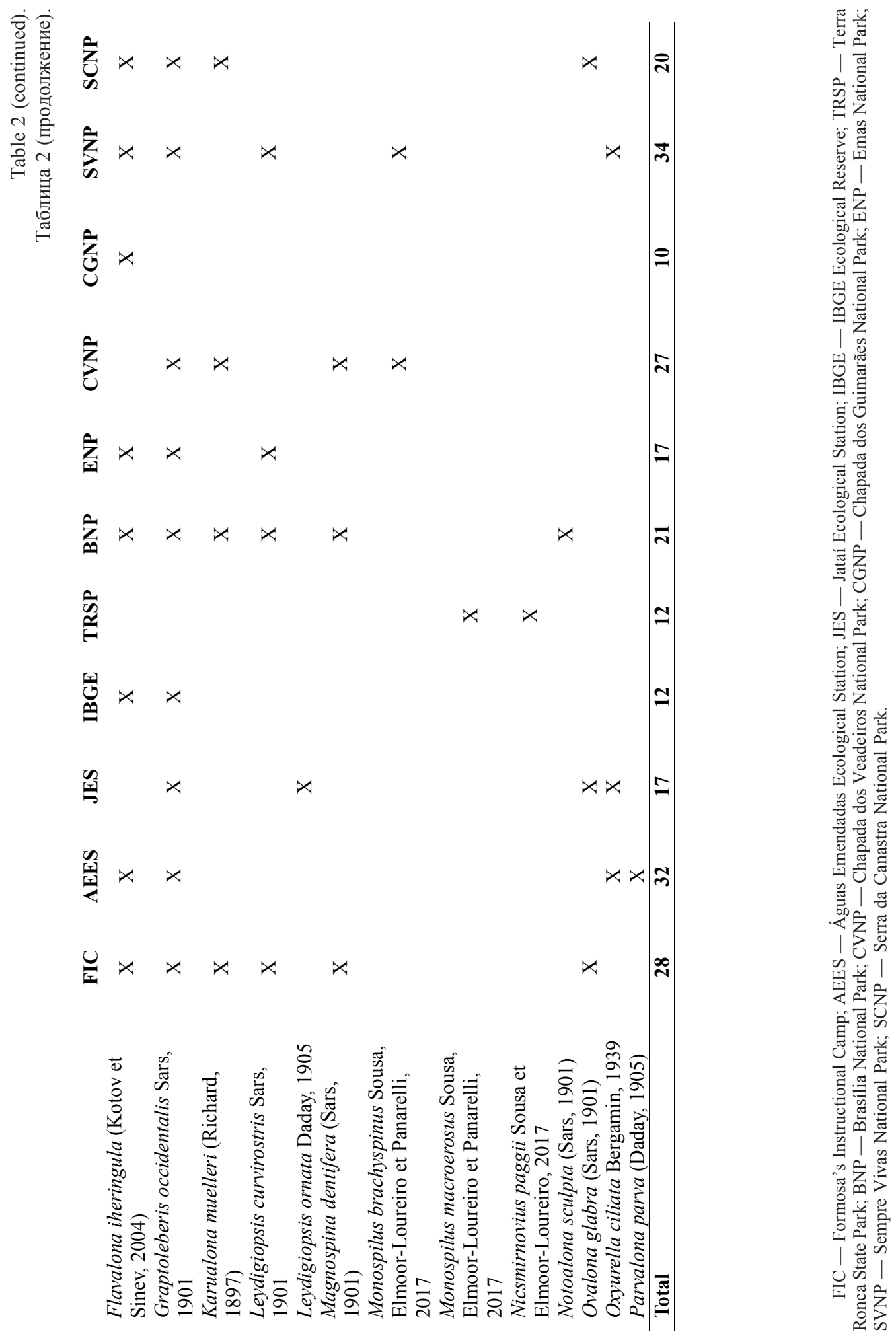

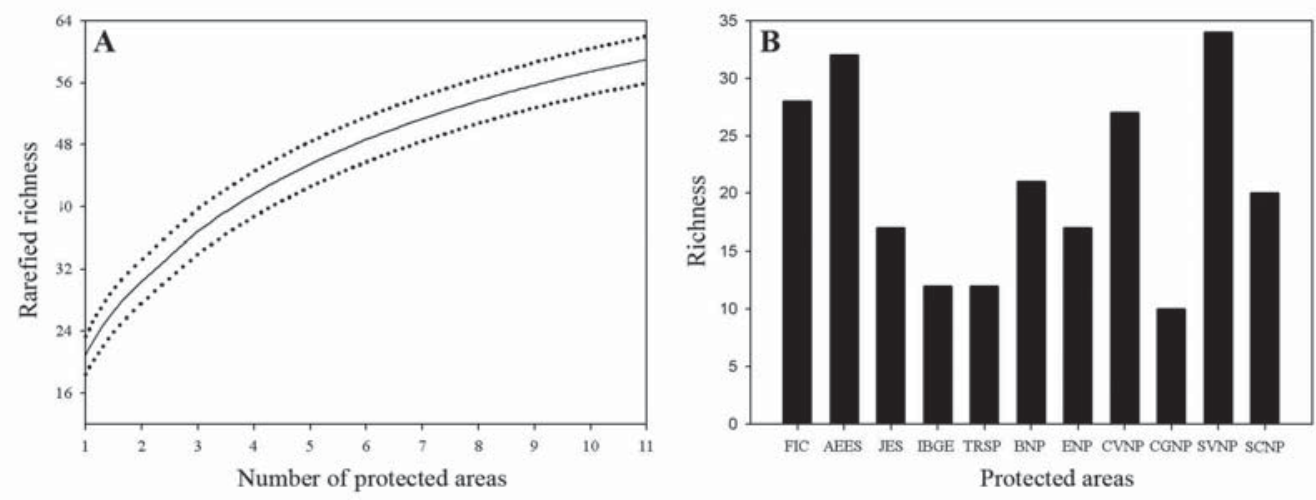

Fig. 2. Species richness observed in the protected areas of the Cerrado Biome. A - rarefied richness (solid line - average, dotted line - standard deviation). B - species richness in different protected areas.

Рис. 2. Видовое разнообразие охраняемых территорий биома серрадо. А - кривая разряжения (сплошная линия - среднее, пунктир - стандартное отклонение). В — видовое богатство отдельных охраняемых территорий.

occupying approximately $47 \%$ of all known species diversity (Forró et al., 2008). In Brazil, the Chydoridae species represent about $53 \%$ of all hitherto recorded taxa (Elmoor-Loureiro, 1997, 2000). More precisely, some species of this family were found exclusively in SCNP, CVNP, FIC, JES, TRSP, BNP, and AEES (Ta- ble 2). Among these species, Monospilus macroerosus and Celsinotum candango are indicated as endemic to the Cerrado Biome (Sinev, Elmoor-Loureiro, 2010; Sousa et al., 2017). Monospilus brachyspinus and Ephemeroporus quasimodo also are considered endemic to this Biome.

Table 3. Similarity among the cladoceran fauna of protected areas of the Cerrado Biome according to Jaccard index.

Таблица 3. Сходство фаун Cladocera охраняемых территорий биома “серрадо” по индексу Жаккара.

\begin{tabular}{|c|c|c|c|c|c|c|c|c|c|c|}
\hline & TRSP & IBGE & CVNP & SVNP & BNP & JES & ENP & AEES & FIC & SCNP \\
\hline IBGE & 0.41 & & & & & & & & & \\
\hline CVNP & 0.30 & 0.30 & & & & & & & & \\
\hline SVNP & 0.24 & 0.31 & 0.52 & & & & & & & \\
\hline BNP & 0.32 & 0.43 & 0.50 & 0.37 & & & & & & \\
\hline JES & 0.31 & 0.45 & 0.25 & 0.30 & 0.31 & & & & & \\
\hline ENP & 0.38 & 0.52 & 0.33 & 0.41 & 0.46 & 0.41 & & & & \\
\hline AEES & 0.25 & 0.37 & 0.40 & 0.46 & 0.39 & 0.40 & 0.40 & & & \\
\hline FIC & 0.25 & 0.37 & 0.52 & 0.40 & 0.63 & 0.40 & 0.45 & 0.46 & & \\
\hline SCNP & 0.23 & 0.45 & 0.38 & 0.28 & 0.46 & 0.32 & 0.48 & 0.36 & 0.45 & \\
\hline CGNP & 0.29 & 0.46 & 0.19 & 0.22 & 0.29 & 0.35 & 0.28 & 0.23 & 0.26 & 0.36 \\
\hline
\end{tabular}

FIC - Formosa's Instructional Camp; AEES - Águas Emendadas Ecological Station; JES — Jataí Ecological Station; IBGE - IBGE Ecological Reserve; TRSP — Terra Ronca State Park; BNP — Brasília National Park; CVNP — Chapada dos Veadeiros National Park; CGNP — Chapada dos Guimarães National Park; ENP — Emas National Park; SVNP - Sempre Vivas National Park; SCNP = Serra da Canastra National Park. 

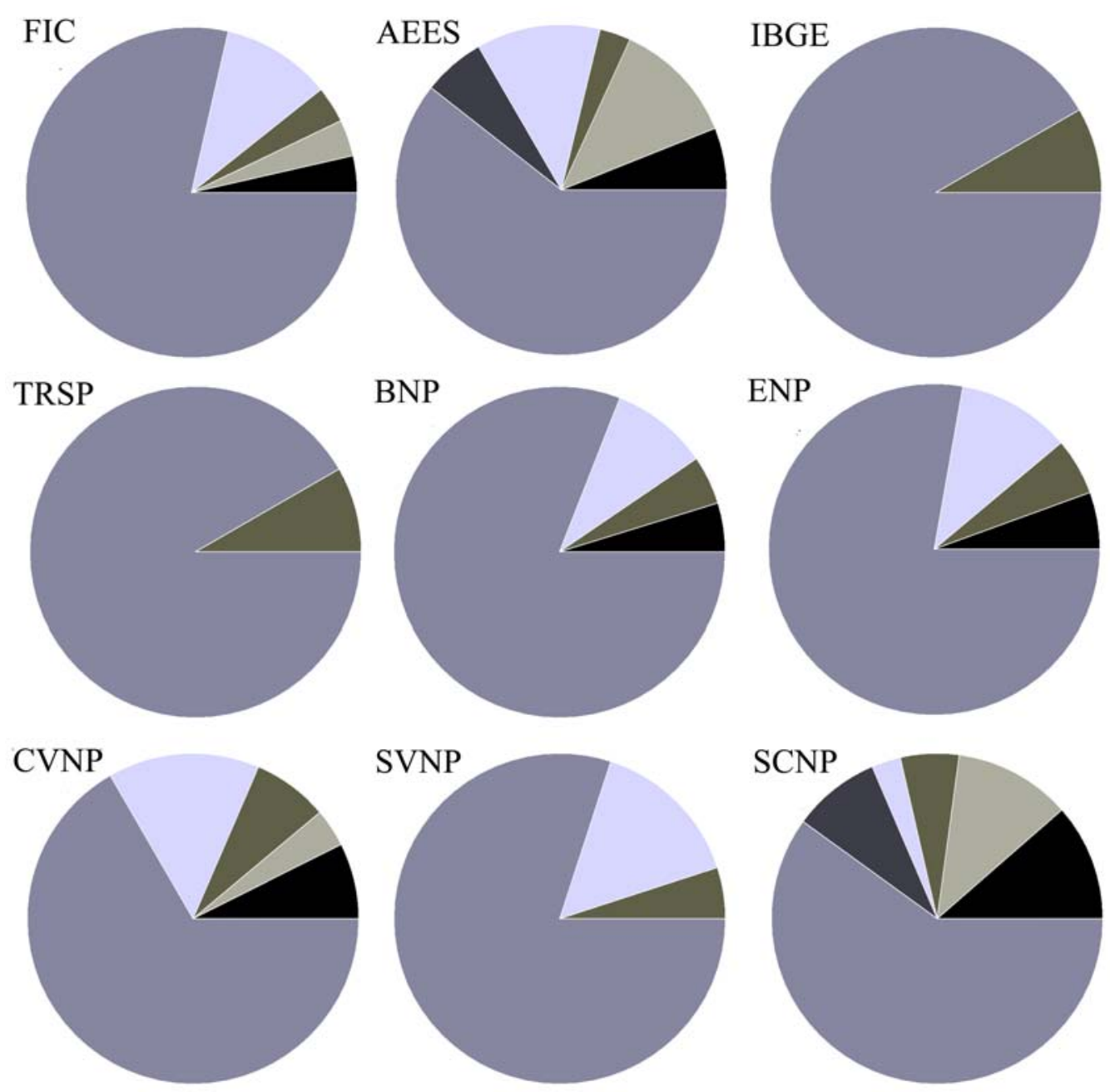

- Sididae

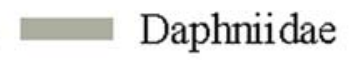

\section{Ilyocryptidae}

\section{Macrotrhicidae}

Bosminidae

\section{Chydoridae}

Fig. 3. Proportional number of species for each Cladocera family observed in different protected areas of the Cerrado Biome. Results for Jataí Ecological Station (JES) and Chapada dos Guimarães National Park (CGNP) were not indicated because they present only Chydoridae species.

Рис. 3. Доля видов, относящихся к различным семействам Cladocera в различных охраняемых районах биома серрадо. Результаты для Jataí Ecological Station (JES) и Chapada dos Guimarães National Park (CGNP) не показаны, поскольку в последних встречены только представители семейства Chydoridae.

Besides Chydoridae species, some Sididae and Daphniidae have also occurred exclusively in SVNP and AEES (Table 2). This fauna specificity and the low values of similarity $(>50 \%)$ among almost all protected areas indicate a particular situation (Table 3). The closer areas represent more similar species composition (BNP, FIC, and AEES; Fig. 4). Nevertheless, it is necessary to keep in mind that both areas lodge the main Cla- 
TRSP

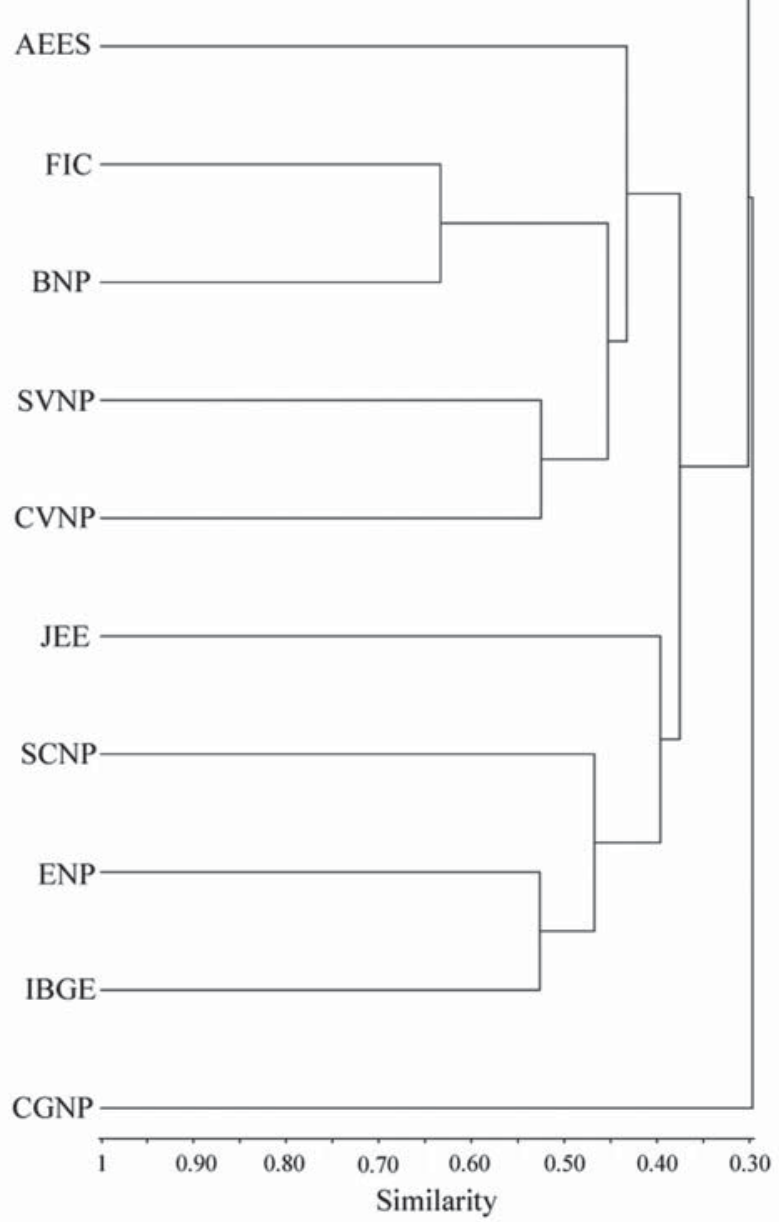

Fig. 4. Cluster analysis resulting from the grouping of the protected areas of the Cerrado Biome. Cophenetic correlation $=0.77$.

Рис. 4. Кластерный анализ сходства охраняемых территорий биома серрадо. Кофенетическая корреляция $=0,77$.

docera lineages, as well a set of particular species. The same could be suggested for the CVNP-SVNP group (Fig. 4).

The studied protected areas of the Cerrado Biome harbor a high diversity of cladocerans. In some Brazilian regions, the observed richness of these areas represents a significant proportion of the regional richness. In addition, the faunal composition indicates different arrangements in each of the evaluated areas, plus pres- ence of endemic species is detected. From this point of view, at least for the Cladocera, the protected areas of the Cerrado Biome fulfill at least one of their primary functions, which is the ability to house different biological components. Nevertheless, the high number of protected areas still need to be investigated in the Cerrado Biome. We can assume that the Cladocera richness and endemism may be higher than it is detected here. 


\section{Acknowledgements}

This study had financial support from CNPq (process 563318/2010-4 SISBIOTA CAMPOS RUPESTRES; process 457431/2012-1 SISBIOTA REDE COMCERRADO) and FNMA (process $02000.005571 / 2005-89$ ). Many thanks to Dr. R.J. Shiel for linguistic corrections of earlier draft.

\section{References}

Bourlière F., Hadley M. 1983. Present-day savannas: an overview // F. Bourlière (ed.). Tropical Savannas, Ecosystems of the world 13. Amsterdan: Elsevier Scientific Publishing Company. P.1-17.

Bustamante M.M.C., Nardoto G.B., Pinto A.S., Resende J.C.F., Takahashi F.S.C., Vieira L.C.G. 2012. Potential impacts of climate change on biogeochemical functioning of Cerrado ecosystems // Brazilian Journal of Biology. Vol.72. P.655-671.

Elmoor-Loureiro L.M.A. 1997. Manual de identificação de cladóceros límnicos do Brasil. Brasília: Universidade de Brasília. 156 p.

Elmoor-Loureiro L.M.A. 2000. Brazilian cladoceran studies: where do we stand? // Nauplius. Vol.8. No.1. P.117-131.

Forró L., Korovichinsky N.M., Kotov A.A., Petrusek A. 2008. Global diversity of cladocerans (Cladocera; Crustacea) in freshwater // Hydrobiologia. Vol.595. P.177-184.

Ganem R.S., Drumond J.A., Franco J.L.A. 2013. Conservation polices and control of habitat fragmentation in the brazilian Cerrado Biome // Ambiente \& Sociedade. Vol.16. P.99-118.

Hammer Ø., Harper D.A.T., Ryan P.D. 2001. PAST: paleontological statistics software package for education and data analysis // Palaeontologica Electronica. Vol.4. P.1-9.

Heny-Silva G.G. 2005. Importância das unidades de conservação na preservação da diversidade biológica // Revista Logos. No.12. P.127-159.

Hermoso V., Abell R., Linke S., Boon P. 2016. The role of protected areas for freshwater biodiversity conservation: challenges and opportunities in a rapidly changing world // Aquatic Conservation: Marine and Freshwater Ecosystems, Supplement. Vol.1. No.1. P.3311.

Klink C.A., Machado R.B. 2005. A conservação do Cerrado brasileiro // Megadiversidade. Vol. 1. No.1. P.147155.

Kotov A.A., Štifter P. 2006. Cladocera: Family Ilyocryptidae (Branchiopoda: Cladocera: Anomopoda). Leiden \& Ghent: Backhuys Publisher/Kenobi Productions. $172 \mathrm{p}$.

Kotov A.A., Garfias-Espejo T., Elías-Gutiérrez M. 2004. Separation of two Neotropical species: Macrothrix superaculeta (Smirnov, 1982) versus M. elegans Sars,
1901 (Macrothricidae, Anomopoda, Cladocera) // Hydrobiologia. Vol.517. P.61-88.

Lawrence D.J., Larson R.E., Liermann C.A.R., Mims M.C., Pool T.K., Olden J.D. 2011. National Parks as protected areas for U.S. freshwater fish diversity // Conservation Letters. Vol.4. P.364-371.

Lima J.E.F.W., Silva E.M. 2005. Estimativa da produção hídrica superficial do Cerrado brasileiro // A. Scariot, J. Sousa-Silva, J.M. Felfili (eds.). Cerrado: Ecologia, Biodiversidade e Conservação. Brasília: Ministério do Meio Ambiente. P.61-72.

Mattar E.D.L., Barros T.T.V., Cunha B.B., Souza J.F., Silva A.M.C. 2018. Federal Conservation Units in Brazil: The Situation of Biomes and Regions // Floresta e Ambiente. Vol.25. No.2. e20150051.

Maury C.M. 2002. Biodiversidade Brasileira: Avaliação e identificação de áreas prioritárias para a conservação, utilização sustentável e repartição dos benefícios da biodiversidade nos biomas brasileiros. Ministerio do Meio Ambiente. Brasília. 404 p.

Myers N. 2003. Biodiversity Hotspots revisited // BioScience. Vol.53. P.916-917.

Myers N., Mittermeier R.A., Mittermeier C.G., Fonseca G.A.B., Kent J. 2000. Biodiversity hotspots for conservation priorities // Nature. Vol.403. P.853-858.

Oliveira U., Soares-Filho B.S.S., Paglia A.P., Brescovit A.D., Carvalho C.J.B., Silva D.P., Rezende D.T., Sá F.F.L., Batista J.A.N. Barbosa J.P.P.P., Stehmann J.R., Ascher J.S., Vasconcelos M.F. De Marco P., Löwenberg-Neto P., Ferro B.G., Santos A.J. 2018. Biodiversity conservation gaps in the Brazilian protected areas // Scientific Reports. Vol.7. e9141.

Padovesi-Fonseca C. 2005. Caracterização dos ecossistemas aquáticos do Cerrado // A. Scariot, J. Sousa-Silva, J.M. Felfili (eds.). Cerrado: Ecologia, Biodiversidade e Conservação. Brasília: Ministério do Meio Ambiente. P.61-72.

Reatto A., Martins E.S. 2005. Classes de solo em relação aos controles da paisagem no bioma Cerrado // A. Scariot, J.C. Sousa-Silva, J.M. Felfili (eds.). Cerrado: Ecologia, Biodiversidade e Conservação. Brasília: Ministério do Meio Ambiente. P.49-59.

Reid J. 1984. Semiterrestrial meiofauna inhabiting a wet campo in central Brazil, with special reference to the Copepoda (Crustacea) // Hydrobiologia. Vol.118. P.95-111.

Reid J. 1987. The cyclopoid copepods of a wet campo marsh in central Brazil // Hydrobiologia. Vol.153. P.121-138.

Reid J. 1993a. The harpacticoid and cyclopoid copepod fauna in the Cerrado Region of Central Brazil. 1. Species composition, habitats, and Zoogeography // Acta Limnologica Brasiliensia. Vol.6. P.56-68.

Reid J. 1993b. The harpacticoid and cyclopoid copepod fauna in the Cerrado Region of Central Brazil. 2. Community structures // Acta Limnologica Brasiliensia. Vol.6. P.69-81.

Santos-Wisniewski M.J., Rocha O., Guntzel A.M., Mastsumura-Tundisi T. 1999. A diversidade de Cladocera Chydoridae de ambientes de diferentes graus de trofia 
da Unidade de Gerenciamento de Recursos Hídricos do Rio Mogi-Guaçu // Estudos integrados em Ecossistema. Estação Ecologica de Jataí. P.408-418.

Santos-Wisniewski M.J., Matsumura-Tundisi T., Negreiros N.T., Silva L.C., Santos R.M., Rocha O. 2011. O estado atual do conhecimento da diversidade de Cladocera (Crustacea, Branchiopoda) nas águas doces do estado de Minas Gerais // Biota Neotropica. Vol.11. No.3. P.287-331.

Silva J.S.O., Bustamante M.M.C., Markewitz D., Krusche A.V., Ferreira L.G. 2011. Effects of land cover on chemical characteristics of streams in the Cerrado region of Brazil // Biogeochemistry Vol.105. P.7588.

Silva F.A.M., Assad E.D., Evangelista B.A. 2008 Caracterização climática do bioma Cerrado // S.M. Sano, S.M.P. Almeida, J.F. Ribeiro (eds). Cerrado: Ecologia e Flora. Brasília: Embrapa Informação Tecnológica. P.69-87.

Sinev A.Yu., Elmoor-Loureiro L.M.A. 2010. Three new species of Chydoridae cladocerans of subfamily Aloninae (Branchiopoda: Anomopoda: Chydoridae) from Brazil // Zootaxa. Vol.2390. P.1-25.

Smirnov N.N. 1992. The Macrothricidae of the world. Amsterdam: SPB Academic Publishing. 143 p.

Smirnov N.N. 1996. Cladocera: The Chydorinae and Sayciinae (Chydoridae) of the world. Amsterdam: SPB Academic Publishing. 197 p.

Sousa F.D.R., Elmoor-Loureiro L.M.A. 2008. Cladóceros fitófilos (Crustacea, Branchiopoda) do Parque Nacio- nal das Emas, estado de Goiás // Biota Neotropica. Vol.8. No.1. P.159-166.

Sousa F.D.R., Elmoor-Loureiro L.M.A. 2012. How many species of cladocerans (Crustacea, Branchiopoda) are found in Brazilian Federal District? // Acta Limnologica Brasiliensia. Vol.24. No.4. P.351-362.

Sousa F.D.R., Elmoor-Loureiro L.M.A. 2013. Cladocerans (Crustacea: Anomopoda and Ctenopoda) of the Sempre Vivas National Park, Espinhaço Range, Minas Gerais, Brazil // Check List. Vol.9. No.1. P.4-8.

Sousa F.D.R., Elmoor-Loureiro L.M.A., Mendonça-Galvão L. 2013. Cladocerans (Crustacea, Anomopoda and Ctenopoda) from Cerrado of Central Brazil: Inventory of phytophilous community in natural wetlands // Biota Neotropical. Vol.13. No.3. P. 222-229.

Sousa F.D.R., Elmoor-Loureiro L.M.A, Panarelli E.A. 2017. The amazing diversity of the genus Monospilus Sars, 1862 (Crustacea: Branchiopoda: Aloninae) in South America // Zootaxa. Vol.4242. P.467-492.

Van Damme K., Kotov A.A., Dumont H.J. 2010. A checklist of names in Alona Baird 1843 (Crustacea: Cladocera: Chydoridae) and their current status: an analysis of the taxonomy of a lump genus // Zootaxa. Vol.2330. P.1-63.

Van Damme K., Sinev A.Yu., Dumont H.J. 2011. Separation of Anthalona gen. n. from Alona Baird, 1843 (Branchiopoda: Cladocera: Anomopoda): morphology and evolution of scraping stenothermic alonines // Zootaxa. Vol.2875. P.1-64.

Responsible editor A.A. Kotov 